\title{
MJN FACTORS INFLUENCING THE HIV PREVENTION EFFORTS AMONG WOMEN IN PEKANBARU
}

\author{
Yulia Irvani Dewi ${ }^{1 *}$, Yufitriana Amir ${ }^{1}$, Febby Fitriyani ${ }^{2}$, Alfiah Arafah ${ }^{3}$ \\ ${ }^{1}$ Faculty of Nursing, University of Riau, Indonesia \\ ${ }^{2}$ The Indonesian National Health Insurance System, Indonesia \\ ${ }^{3}$ Nurse Practioner in Awalbros Hospital, Indonesia \\ *Corresponding Author’s Email: yulia.irvanidewi@lecturer.unri.ac.id
}

\begin{abstract}
HIV prevalence among women increases every year and it has become a major health problem among women. Housewives are at risk to be infected with HIV from their husbands. Women and girls are prone to be infected twice more with HIV than their men counterparts. The seriousness of HIV/AIDS stems from the risks it brings. It does not affect the individuals infected, but also seriously influences the HIV prevention efforts. Indonesia have been going well with emphasis on curative efforts of HIV prevention and control programs but need more to be optimal. This study analyzed the influence of factors HIV prevention efforts among women in Pekanbaru. Methods: The study involved 194 women aged 20-50 and currently married and living together with their husbands. Descriptive analysis was used to determine the demographic characteristics. A quantitative descriptive with multivariate analysis using logistic regression was conducted amongst women in both district between of Tenayan Raya and Rumbai Pesisir Pekanbaru, Riau Province in 2018. A systematic random sampling technique was used to select 194 women. Data were collected through structured quessionaire. The data were entered into Epi Info and analyzed by using SPSS for windows. Results: Out of the 194 women, findings indicated the factors that influenced the prevention efforts by women using a significance of $p$-value $<0.005$ were: working $(p=0.000, \mathrm{OR}=3.781,95 \% \mathrm{CI}=1.859-7.688)$; knowledge $(p=0.000, \mathrm{OR}=0.295,95 \% \mathrm{CI}=0.154-0.564)$; attitude $(p$ value $=0.027, \mathrm{OR}=0.161,95 \% \mathrm{CI}=0.32-0.809)$. Employment was found to be the most significant factor in this study. This finding implies that women who do not work need special attention and are encouraged to conduct HIV prevention efforts through education and personal approaches.
\end{abstract}

Keywords: Attitude; HIV; Knowledge; Prevention efforts; Women; Working

\section{INTRODUCTION}

The United Nations Program on HIV/AIDS (UNAIDS) reports that the number of women infected with HIV/AIDS is increasing every year. In 2017 there were 18.2 million women infected with HIV/AIDS in the world. While in Indonesia, there were 48,300 cases during 2017 and the highest group was found in the age range of $25-49$ years (69.3\%). In terms of gender, $73.6 \%$ of the infected victims were men and $36.4 \%$ of others were women. Cases of HIV were initially only found in groups of sex workers, drug users or homosexuals, but lately, it continues to spread without exception to vulnerable people including housewives. Transmission of HIV/AIDS to housewives is most likely due to unsafe sexual intercourse with a permanent partner, namely the husbands (WHO, 2017b).

An increase in the incidence of HIV/AIDS also occurred in Riau province. In 2017 there were 711 cases of HIV and 383 cases of AIDS found in Riau. The number of HIV cases increased to be 294 cases in 2018 (January-June). The highest transmission occurs through heterosexual which is $72 \%$. The incidence of AIDS among housewives is found to be the second-highest transmission with 15,410 cases (Director General of Disease Control and Prevention Ministry of Health Indonesia, 2018).

The data illustrates that the problem of HIV/AIDS is a global health problem that needs to be taken 
seriously. Women, especially housewives, are a vulnerable group that needs special attention. Several factors make women vulnerable groups such as weak bargaining power and negotiation in sexual intercourse. Besides, women are also unable to ask about their husbands' sexual behavior. Inequality is sharper if women depend economically on their husbands (Higgins, Hoffman \& Dworkin, 2010). According to the theory of feminism, the construction of the culture of society places the position of women and men in the family as not equal. This worsens the condition of women if they are infected with HIV/AIDS even from their own husbands. Housewives with HIV/AIDS tend to have a double burden such as caring for their husbands, children, themselves, earning a living and sometimes getting discrimination and negative stigma from the social environment (UNAIDS, 2017b).

Other risk factors are biological, knowledge, attitudes, economic, social, cultural, religious, poverty, gender inequality, unequal access to education and health services (UNAIDS, 2017 \& WHO, 2017c; Cianelli, Ferrer \& McElmurry, 2008). The dominant factor of vulnerable women infected with HIV/AIDS is their relatively low level of knowledge about HIV/AIDS and prevention efforts. The Zarei et al., in Iran (2018) explain that $78.5 \%$ of women aged $15-49$ have heard about HIV/AIDS. Only $19.1 \%$ of these women have comprehensive knowledge about HIV/AIDS. This phenomenon also happens in some other developing and underdeveloping countries such as Ethiopia (19.3\%) and Uganda (38\%) (Teshome et al., 2016; Ankunda \& Asiimwe, 2017). Less than half of the women population were found to have comprehensive knowledge about HIV/AIDS. The results of a survey conducted by the Indonesian Central Statistics Agency in 2013 showed that $57.06 \%$, of women aged $15-49$ years had heard about HIV. To be specific in Riau province, data shows that $71.69 \%$ have heard about HIV/AIDS. From the survey, it was found that the understanding of women towards HIV/AIDS was still low. Dewi \& Safitri's research (2017) found that the understanding of women (housewives) in the city of Pekanbaru about HIV/AIDS was low. They seemed to have wrong perceptions about HIV transmission and tended to be introvert with their husbands' sexual behavior.

If this phenomenon is not taken seriously, it will certainly be a threat to women and future generations.
At present, there is no medicine to kill HIV or cure HIV/AIDS. There is only medicine to suppress the rate of development of the virus, namely Antiretroviral (WHO, 2017a). Therefore, one effective step to reduce the rate of HIV transmission is through HIV/AIDS prevention and control programs that do not only focus on key populations (female sex workers, injecting drug users, homosexuals, transgenders and prisoners) but also involves the women themselves. Women have an important role in the family and community structure in overcoming the problem of the spread of HIV/AIDS. Awareness of the threat of HIV/AIDS and proper knowledge about HIV/AIDS are expected to be able to suppress the spread of HIV/AIDS. Health education by strengthening women's knowledge is effective as an effort to empower women. During this time the focus of the government or holders of HIV/AIDS programs is to develop preventive and curative actions for high-risk groups. There is no real action seen in groups of women or housewives. In fact, they are a vulnerable group infected with HIV from their husbands.

Based on the results of the focus group discussion (FGD) with stakeholders in Pekanbaru City in 2017, it was found that some problems became the obstacles to why women are in a circle of vulnerability to HIV infection. The stakeholders involved in the FGD are those in charge of the HIV/AIDS program in Riau Province Health department, leaders of the HIV/AIDS program in the Pekanbaru Health Office, the Pekanbaru AIDS prevention commission, those in charge of the HIV/AIDS program at the Tenayan Raya Health Center and Rumbai Pesisir, personnel of Women Empowerment Department of Pekanbaru, and activists of NGOs engaged in the field of HIV/AIDS). According to the FGD conclusions and recommendations, the main problem that occurs is the women's lack of knowledge about the causes, mode of transmission, treatment, and prevention of HIV/AIDS. In addition, there is a wrong assumption among some women, that they won't be infected with HIV/AIDS because they are confident with their behavior. They have full trust in their husbands not to have sexual intercourse with others, especially women who are sex workers. This study aims to analyze the factors that influence HIV prevention efforts by women in Pekanbaru.

\section{METHODOLOGY}

A quantitative descriptive study with multivariate analysis using logistic regression was conducted on 
women in both districts with the highest incidence of HIV/AIDS in the city of Pekanbaru, namely Tenayan Raya and Rumbai Pesisir Pekanbaru, Riau Province from March to August 2018. A systematic random sampling technique was used to select 194 women. Data were collected through a structured questionnaire that had been tested for validity and reliability. Ethical clearance of this study was approved and issued by the Faculty of Medicine, University of Riau (345/UN. 19.5.1.8/UEPKK/2017).

\section{RESULTS}

\section{Demographic Characteristics}

Table 1 shows that the majority of women studied were aged more than 35 years $(60.3 \%)$. Only $39.7 \%$ were aged 20-30 years old. About $66 \%$ of the participants did not work and around half of them were in high education level (64.9\%). On average, participants have got married for more than ten years $(61.9 \%)$. The demografic characteristics of study respondents are presented in Table 1.

Table 1: Demographic Characteristics of 194 Subjects in Pekanbaru, 2018

\begin{tabular}{|l|c|c|}
\hline \multirow{2}{*}{ Variables } & \multicolumn{2}{|c|}{ (n=194) } \\
\cline { 2 - 3 } & n & \% \\
\hline Age (Years) & 77 & 39.7 \\
$20-35$ & 177 & 60.3 \\
$>35$ & & \\
\hline Working & 128 & 66 \\
Not Working & 66 & 34 \\
Working & & \\
\hline Educational level & 68 & 35.1 \\
Low of education (Junior \& Senior & & 64.9 \\
high school) & 126 & 38.1 \\
High of education (Academic) & & 61.9 \\
\hline Marriage Duration & 74 & \\
$<10$ Years & 120 & \\
$\geq 10$ Years & & \\
\hline
\end{tabular}

Table 2: Bivariate Analysis Factors That Influenced the HIV Prevention Efforts among Women in Pekanbaru

\begin{tabular}{|c|c|c|c|c|c|c|c|c|c|}
\hline \multirow[t]{3}{*}{ Variables } & & \multicolumn{4}{|c|}{$\begin{array}{l}\text { Prevention Effort } \\
\end{array}$} & \multirow[t]{3}{*}{$p$} & \multirow[t]{3}{*}{ OR } & \multicolumn{2}{|c|}{ IK 95\% } \\
\hline & & \multicolumn{2}{|c|}{ Not Well } & \multicolumn{2}{|c|}{ Well } & & & Min & x Ma \\
\hline & & $\mathrm{n}$ & $\%$ & $\mathrm{n}$ & $\%$ & & & & \\
\hline \multirow[t]{2}{*}{ Age (years) } & $<35$ years & 50 & 47.2 & 27 & 30.7 & \multirow[t]{2}{*}{$0.019 *$} & \multirow[t]{2}{*}{2.017} & \multirow[t]{2}{*}{1.116} & \multirow[t]{2}{*}{3.647} \\
\hline & $\geq 35$ years & 56 & 52.8 & 61 & 69.3 & & & & \\
\hline \multirow[t]{2}{*}{ Educational Level } & Low & 46 & 43.4 & 22 & 25 & \multirow[t]{2}{*}{$0.008^{*}$} & \multirow[t]{2}{*}{2.300} & \multirow[t]{2}{*}{1.241} & \multirow[t]{2}{*}{4.262} \\
\hline & High & 60 & 56.6 & 66 & 75 & & & & \\
\hline \multirow[t]{2}{*}{ Working } & Not Working & 59 & 55.7 & 69 & 78.4 & \multirow[t]{2}{*}{$0.001 *$} & \multirow[t]{2}{*}{0.346} & \multirow[t]{2}{*}{0.183} & \multirow[t]{2}{*}{0.053} \\
\hline & Working & 47 & 44.3 & 19 & 21.6 & & & & \\
\hline \multirow[t]{2}{*}{ Marriage Duration } & $<10$ years & 44 & 41.5 & 30 & 34.1 & \multirow[t]{2}{*}{0.290} & \multirow[t]{2}{*}{1.372} & \multirow[t]{2}{*}{0.764} & \multirow[t]{2}{*}{2.466} \\
\hline & $\geq 10$ years & 62 & 58.5 & 58 & 65.9 & & & & \\
\hline \multirow[t]{2}{*}{ Knowledge } & Low & 65 & 61.3 & 27 & 30.7 & \multirow[t]{2}{*}{$0.000^{*}$} & \multirow[t]{2}{*}{3.582} & \multirow[t]{2}{*}{1.969} & \multirow[t]{2}{*}{6.516} \\
\hline & High & 41 & 38.7 & 61 & 69.3 & & & & \\
\hline \multirow[t]{2}{*}{ Attitude } & Negative & 104 & 98.1 & 76 & 86.4 & \multirow[t]{2}{*}{$0.002 *$} & \multirow[t]{2}{*}{8.211} & \multirow[t]{2}{*}{1.785} & \multirow[t]{2}{*}{37.762} \\
\hline & Positive & 2 & 1.9 & 12 & 13.6 & & & & \\
\hline
\end{tabular}

Note. $* p<0.05$ significant

Table 3 explains that the most influencing variables in the efforts to prevent HIV / AIDS by women are employment, knowledge, and attitudes. Relationship strength is work $(\mathrm{OR}=3.781)$, knowledge $(\mathrm{OR}=$
$0.295)$, and attitude $(\mathrm{OR}=0.161)$. Thus, the proportion of women's work to make efforts to prevent HIV/AIDS in Pekanbaru is $79.08 \%$, knowledge $22.77 \%$, and attitude $13.87 \%$.

Table 3: Multivariate Analysis (Logistic Regression)

\begin{tabular}{|c|c|c|c|c|c|c|}
\hline \multicolumn{2}{|c|}{} & Coefficient & $p$ & OR & \multicolumn{2}{c|}{ 95\% C.I.for EXP(B) } \\
\hline \multirow{5}{*}{} & Age(1) & -0.612 & 0.191 & 0.542 & 0.217 & 1.356 \\
\cline { 2 - 7 } & Education(1) & -0.513 & 0.157 & 0.598 & 0.294 & 1.218 \\
\cline { 2 - 7 } Step 1 & Working(1) & 1.199 & 0.001 & 3.317 & 1.614 & 6.814 \\
\cline { 2 - 7 } & Marriage Duration(1) & 0.249 & 0.587 & 1.282 & 0.523 & 0.182 \\
\cline { 2 - 7 } & Knowledge(1) & -1.018 & 0.004 & 0.361 & 0.034 & 0.719 \\
\cline { 2 - 7 } & Attitude(1) & -1.758 & 0.033 & 0.172 & & \\
& Constant & 1.439 & 0.076 & 4.215 & & \\
\hline
\end{tabular}




\begin{tabular}{|c|c|c|c|c|c|c|}
\hline & & Coefficient & $p$ & OR & $95 \%$ & \\
\hline \multirow{6}{*}{ Step $2^{\mathrm{a}}$} & Age(1) & -0.442 & 0.200 & 0.642 & 0.327 & 1.264 \\
\hline & Education(1) & -0.514 & 0.156 & 0.598 & 0.294 & 1.216 \\
\hline & Working(1) & 1.213 & 0.001 & 3.363 & 1.638 & 6.905 \\
\hline & Knowledge(1) & -1.017 & 0.004 & 0.362 & 0.182 & 0.719 \\
\hline & Attitude(1) & -1.767 & 0.033 & 0.171 & 0.034 & 0.865 \\
\hline & Constant & 1.467 & 0.071 & 4.335 & & \\
\hline \multirow{5}{*}{ Step $3^{\mathrm{a}}$} & Education(1) & -0.416 & 0.236 & 0.660 & 0.332 & 1.313 \\
\hline & Working(1) & 1.282 & 0.000 & 3.603 & 1.766 & 7.352 \\
\hline & Knowledge(1) & -1.114 & 0.001 & 0.328 & 0.168 & 0.641 \\
\hline & Attitude(1) & -1.835 & 0.027 & 0.160 & 0.032 & 0.808 \\
\hline & Constant & 1.322 & 0.101 & 3.752 & & \\
\hline \multirow{4}{*}{ Step $4^{\mathrm{a}}$} & Working(1) & 1.330 & 0.000 & 3.781 & 1.859 & 7.688 \\
\hline & Knowledge(1) & -1.222 & 0.000 & 0.295 & 0.154 & 0.564 \\
\hline & Attitude(1) & -1.826 & 0.027 & 0.161 & 0.032 & 0.809 \\
\hline & Constant & 1.187 & 0.135 & 3.278 & & \\
\hline
\end{tabular}

\section{DISCUSSION}

As the incidence of HIV/AIDS in women increases, effective prevention efforts are needed by involving crosssectoral collaboration among government, private parties, and the community, including women. HIV/AIDS prevention strategies include health education, sexual and reproductive health services, behavior changes, and training. The activity is aimed at empowering women, gender equality and increasing responsibilities of partners' (husbands') in preventing HIV (Frasca, 2005). Various efforts have been made to tackle HIV/AIDS in Indonesia, as well as in Pekanbaru, both counseling at health centers, and directly plunging into the community through community activities such as social gathering, religious events, and other events. These activities aim to increase community participation especially among women to increase knowledge about HIV/AIDS and behavior changes. However, not all women are willing to participate and utilize health services about HIV/AIDS.

The results of the study illustrate that the variables that influence the prevention of HIV by women in Pekanbaru are employment, knowledge, and attitudes. Employment is the most influential variable in efforts to prevent HIV by women in Pekanbaru ( $p$-value $=0.000$, OR 3781). Women who do not work will have an opportunity of 3.781 times to prevent HIV more than women who work. The majority (66\%) of respondents are either unemployed or housewives. Unemployed women or housewives have free time and opportunities to receive and seek information about HIV/AIDS. Information received, not only from the socialization by the Tenayan Raya and Rumbai Pesisir Health Centre but also from the media both printed and electronic media. This can be seen that women who actively participate in HIV/AIDS socialization activities have a better understanding and willing to do Voluntary Counseling and Testing.

The results also indicate that knowledge was an influential factor in efforts to prevent HIV ( $p$-value $0.000, \mathrm{OR}=0.295)$. Thus, women with high knowledge have the opportunity of 0.295 times to prevent HIV compared to women who have low knowledge. One supporting factor in increasing knowledge and prevention behavior is age and education level. Respondents aged $>35$ years did good prevention efforts against HIV. This age is a productive age when a person will easily accept and actively seek information related to HIV. Also, higher education is associated with good prevention efforts $(75 \%)$. The higher level of education will make it easier to accept the information provided. Research survey in three East African Countries 
(Burundi, Ethiopia, and Kenya) conducted by Teshome (2016) found that higher education is closely related to high knowledge about HIV/AIDS.

Knowledge is one of the important components in forming one's attitude and one's behavior. Besides, Notoatmodjo (2010) explains that other factors are values, perceptions, supporting factors such as facilities and infrastructure that can facilitate and support positive behavior changes, laws, regulations, and decisions. A positive attitude will be reflected in knowledge and behavior in preventing HIV/AIDS. The results of the study found that attitudes affected the efforts to prevent HIV by women in the city of Pekanbaru ( $p$-value 0.027 , OR 0.161 ). About $98.1 \%$ of respondents with negative attitudes did not make prevention efforts well enough. Ayuningtias, Solehati, \& Maryati's research (2018) explained that $52.7 \%$ of women's attitudes were unfavorable towards the prevention of HIV/AIDS transmission. Ariani \& Hargono (2012) state that there is a relationship between attitudes and HIV/AIDS prevention measures for women sex workers. Negative attitudes possessed by these women may be caused by several factors including the perception that it is impossible for their husbands can be infected with HIV. They trust their husband's sexual behavior, lack of information, lack of knowledge, lack of support and fear of the results of HIV testing (Setiyawati, Shaluhiyah \& Cahyo, 2014; Juliastika, 2011; Fadhali et al., 2012).

\section{CONCLUSION}

The majority of the research participants $(60.3 \%)$ were more than 35 years old. Around sixty-six of the participants had no work. Approximately half of the participants were a high level of education (64.9\%). On average, participants have got married for more than ten years $(61.9 \%)$. The results of the chi-square analysis show that there are several variables related to HIV prevention by women in Pekanbaru, namely age ( $p$ 0.019 , education ( $p 0.008)$, occupation ( $p 0.001)$, knowledge ( $p 0.000)$, attitude ( $p$ 0.002), and unrelated variables such as length of marriage $(p$ 0.290). The variables that most influence the efforts to prevent HIV by women are employment, knowledge, and attitude The strength of the relationship is employment $(\mathrm{OR}=$ 3.781), knowledge $(\mathrm{OR}=0.295)$, and attitude $(\mathrm{OR}=$ 0.161 ). Thus, the probability of working women to prevent HIV in Pekanbaru is $79.08 \%$; knowledge is $22.77 \%$; attitude is $13.87 \%$. Based on the findings of this research, women are suggested to increase their independence and awareness of risk behaviors infected with HIV by making prevention efforts. They could do this by actively participating and involving in HIV communication, information and education programs and conducting voluntary counseling and testing with partners.

\section{Conflict of Interest}

The authors declare that they have no conflict of interest.

\section{ACKNOWLEDGEMENT}

This project was supported by the Indonesian Ministry of Research, Technology and Higher education.

\section{REFERENCES}

Ankunda, D., \& Asiimwe, J.B. (2017). Determinants of comprehensive knowledge of HIV/AIDS among women of the reproductive age (15-49) in Uganda. International Journal of Community Medicine and Public Health, 4(10), $3530-3535$.

Ariani, D., \& Hargono, A. (2012). Analisis hubungan antara pengetahuan, sikap dengan tindakan berdasarkan indikator surveilans perilaku HIV/AIDSaids pada wanita pekerja seks. Journal Kesehatan Masyarakat Universitas Airlangga.

Ayuningtias, R., Solehati, T., \& Maryati, I. (2018). Pengetahuan dan Sikap Perempuan yang Sudah Menikah Terhadap Pencegahan Penularan Human Immunodeficiency Virus/Acquired Immune Deficiency Syndrome (HIV/AIDS). Journal Aisyah: Journal Ilmu Kesehatan, 3(2), 153-162.

Cianelli, R., Ferrer, L., \& McElmurry, B.J. (2008). HIV prevention and low-income Chilean women: machismo, marianismo and HIV misconceptions. Culture, Health \& Sexuality, 10(3), 297-306.

Direktoral Jenderal Pencegahan dan Pengendalian Penyakit Kementrian Kesehatan Republik Indonesia (2018). Laporan perkembangan HIV-AIDS \& Infeksi Menular Seksual (IMS) Triwulan II tahun 2018. Retrieved from: 
http://siha.depkes.go.id/ .

Dewi, Y.I., \& Safitri, A. (2017). Pencegahan Hiv/Aids Oleh Perempuan Di Kota Pekanbaru. Journal Ners Indonesia, $8(1), 15-22$.

Fadhali, A., Amiruddin, R., \& Ansar, J. (2012). Faktor yang berhubungan dengan pencegahan HIV dan AIDS di kalangan pramusaji kafe di tanjung bira kabupaten bulukumba relating factors to hiv and aids prevention among waiters cafe in bira beach bulukumba. Journal Keperawatan Universitas Islam Makasar.

Frasca, T. (2005). Women and HIV/AIDS: Confronting the crisis. Reproductive Health Matters, 13(25), 182-183.

Higgins, J.A., Hoffman, S., \& Dworkin, S.L. (2010). Rethinking gender, heterosexual men, and women's vulnerability to HIV/AIDS. American Journal of Public Health, 100(3), 435-445.

Indonesia, S. (2012). National Family Planning Coordinating Board, Ministry of Health Republic of Indonesia. Indonesia Demographic and Health Survey.

Joint United Nations Programme on HIV/AIDS and Joint United Nations Programme on HIV/Aids, (2017a). UNAIDS data 2017. Geneva: UNAIDS.

Joint United Nations Programme on HIV/AIDS (UNAIDS), (2017b). Ending AIDS: Progress towards the 90-90-90 targets. Global AIDS update.

Juliastika, J., Korompis, G.E., \& Ratag, B.T. (2012). Hubungan Pengetahuan tentang HIV/AIDS dengan Sikap dan Tindakan Penggunaan Kondom Pria pada Wanita Pekerja Seks di Kota Manado. KESMAS, 1(1), 15-20.

Notoatmodjo, S. (2010). Promosi kesehatan teori dan aplikasi. Rineka Cipta, Jakarta.

Setiyawati, N., Shaluhiyah, Z., \& Cahyo, K. (2014). Sikap Ibu Rumah Tangga Terhadap Tes HIV/AIDS di Sleman Yogyakarta. Journal Promosi Kesehatan Indonesia, 9(1), 56-66.

Teshome, R., Youjie, W., Habte, E., \& Kasm, N.M. (2016). Comparison and association of comprehensive HIV/AIDS knowledge and attitude towards people living with HIV/AIDS among women aged 15-49 in three east African countries: Burundi, Ethiopia and Kenya. Journal of AIDS and Clinical Research, 7(04), 1-8.

World Health Organization (2017a). Guidelines for managing advanced HIV disease and rapid initiation of antiretroviral therapy, July 2017. Retrieved from: https://apps.who.int/iris/bitstream/handle/10665/255884/9789241550062eng.pdf? sequence $=1$

World Health Organization (2017b). Consolidated Guideline on Sexual and Reproductive Health and Rights of Women Living with HIV. World Health Organization.

World Health Organization (2017c). Kajian Nasional Respon HIV di Bidang Kesehatan Republik Indonesia. Laporan WHO untuk Indonesia. Retrieved from: https://www.who.int/docs/default-source/searo/indonesia/non-whopublications/2017-hiv-country-review-indonesia-bahasa.pdf?sfvrsn=76cca118_2.

Zarei, E., Khabiri, R., Tajvar, M., \& Nosratnejad, S. (2018). Knowledge of and attitudes toward HIV/AIDS among Iranian women. Epidemiology and Health. 